Jpn. J. Crop Sci. 63(4) : 664-670 (1994)

\title{
Remote and Real-Time Sensing of Canopy Transpiration and Conductance-Comparison of Remote and Stem Flow Gauge Methods in Soybean Canopies as Affected by Soil Water Status-
}

\author{
Yoshio Inoue, Tetsuo Sakuratani*, Michio Shibayama** \\ and Shinsuke MORINAGA \\ (National Institute of Agro-Environmental Sciences, Tsukuba 305, Japan ; \\ ${ }^{*}$ Kyoto University, Kyoto 606, Japan; ${ }^{* *}$ National Grassland \\ Research Institute, Nishinasuno 329-27, Japan) \\ Received March 15, 1994
}

\begin{abstract}
A newly developed remote and real-time method for estimating transpiration rates and conductance of crop canopies is examined in comparison with concurrent measurements by the stem flow gauge method. The remote method is based on the energy balance of a plant canopy, which uses the net radiation absorbed by the canopy and the remotely sensed canopy temperature as key inputs. Measurements were made on droughtstressed, waterlogged, and periodically-irrigated soybean canopies. Canopy transpiration values used for verification of the remote method were calculated from the mean transpiration rates per unit leaf area measured by the hand-made stem flow gauges, and the leaf area index obtained by destructive sampling. The raw measurements by the gauge show that the transpiration values for individual plants were well-synchronized and responded very well to the change of environmental factors such as solar radiation and windspeed. Although the plant-to-plant difference was dominated by the difference in the leaf area, it was larger under clear sky conditions than under cloudy conditions. Canopy transpiration values derived from the remote method are compared with those by the stem flow gauge method from three different aspects : 1) diurnal time course for a particular canopy, 2) one-to -one comparison of ten-minute mean values for all soil water conditions, and 3) daily total values for all soil and meteorological conditions. The results indicated that the remote method provides reasonable estimates of canopy transpiration and conductance over a wide range of soil water status and micrometeorological conditions on an instantaneous or daily basis. The method allows continuous measurements of these canopy parameters under natural conditions with neither plant sampling nor disturbing the micrometeorological environment of the canopy. Key words : Canopy conductance, Infrared thermometry, Remote sensing, Soybean, Stem flow gauge, Transpiration, Waterlogging, Water stress.
\end{abstract}

作物個体群蒸散速度および植被コンタクタンスのリアルタイム這亚計測一土燷水分变動下のタイス個体群に おける遠隔法と蕉熟収支法の比較一 : 井上吉雄・桜谷哲夫*・芝山道郎**・森永慎介（農業環境技術研究所・ *京都大学農学部・**草地試験場)

要 旨:作物の個体群蒸散速度扔よび植被コンダクタンスをリアルタイムで遠隔的に評価する手法を開発し た。遠隔法は個体群についての熱収支モデルに基づいており，遠隔計測される植被温度および個体群に吸収 される純放射エネルギを主要な入力とするものである，干ばつ，灌水，湛水の各土壤水分条件下にあるダイ ズ個体群について，同手法による推定值と茥熱収支法による測定値とを比較検討した．萃熱収支法による個 体群蒸散速度の值は，自作した茎熱収支法ゲージによる個体蒸散速度と破壞サンプリングによる葉面積から 求められた。茎熱収支法を用いて測定した個体蒸散速度は日射強度や風速の変化によく応答して変動し，か つ反復個体の変動は非常に上く同期していた。個体間の蒸散速度の差は抢もに葉面積の差に支配されていた が，散乱光条件下よりも直達光条件で挔大する傾向があった。遠隔法と蕉熱収支法から求めた個体群蒸散速 度を，1）同一個体群についての日変化，2）3つの土壤水分処理の影響が大きく現れた日の全区の 10 分当た り平均値，3）3種の土䁃水分条件における全測定日の日蒸散量，の3つの角度から比較した。その結果，多 样な土壤水分ならびに微気象条件下において，遠隔法が個体群蒸散速度と植被コンダクタンスの正確な推定 值を与えることがわかった。本方法により，サンプリングや周辺環境の擋乱を伴わずに，野外条件で植物個 体群レベルの蒸散速度，コンダクタンスを連続的に評価できる可能性が示された。

キーワード：過湿，茎熱収支法，植被コンダクタンス，蒸散，水分ストレス，赤外線測温，ダイズ，リモート センシング. 
Water deficit and excess moisture have been the major problems in agricultural production. Both the efficient water use and the improvement of water use efficiency of crops are essential in agricultural water management ${ }^{22)}$. Similarly, monitoring of natural vegetation on a regional scale, especially in water-limited and/or temperature-limited regions, is of great importance for estimating vegetation response to global climate change such as desertification and movement of boundaries between different vegetation types ${ }^{25}$.

Therefore, it is crucial to understand the dynamics of water consumption, canopy conductance, and water use efficiency of vegetated surfaces under non-optimal water conditions. Simpler and more robust methods are required for estimating the vegetation water use at canopy-, local- and regional-scales ${ }^{13)}$.

Evapotranspiration has long been measured with a lysimeter-method and by several meteorological methods. However, these methods are unable to provide separate estimates of transpiration from plants and evaporation from soil or water surfaces. As for the transpiration alone the heat pulse method ${ }^{3)}$ and the heat balance method ${ }^{2,20)}$ (which both need to attach gauges to plant stems) have been applied to the estimation of sap flow rates of individual plants. Recently, accuracy of these two methods were examined by Cohen et al. ${ }^{4)}$, and they concluded that the heat balance method using a stem flow gauge does provide an accurate estimate of sap flow rate except for some unstable environmental conditions. The stem flow gauge method, so far, seems to be the most reliable method for the estimation of transpiration from individual plants in the field, although it requires attaching a number of delicate sensors to plant stems.

Hence, remote sensing methods are expected to provide useful information on the water status of both crop canopies and natural vegetation. Remote sensing techniques for estimating regional evapotranspiration have been investigated based on satellite data $^{12,16,18)}$. There is a evidence that leaf or canopy temperatures are both useful for detecting plant stress response ${ }^{7,9,11,17)}$ and for estimating transpiration rates of single leaves ${ }^{8)}$. However, few remote methods are available for in-situ estimation of the transpiration from plants on a canopy scale. Furthermore, a comparative examination has never been made between the direct measurements of transpiration with the stem flow gauge method and canopy transpiration estimates based on remote sensing.

In this paper, we report on a newly developed method for monitoring the transpiration dynamics of vegetation canopies as affected by soil water status. The method is based on remotely sensed thermal and micrometeorological data, which will enable the estimation of these canopy parameters on a remote and real-time basis with neither plant sampling nor disturbing the micrometeorological environment of the canopy. Estimates by the remote method were compared with those measured concurrently with the hand-made stem flow gauges.

\section{Materials and Methods}

\section{Experimental plots}

Three soybean varieties [Enrei, Tachinagaha and Harosoy (Glycine max Merr.)], were grown in eighteen lysimeter plots $(3 \mathrm{~m} \times 3 \mathrm{~m}, 2$ $\mathrm{m}$ depth). Before flowering stage all plots were under rain-fed conditions. Thereafter, all rainwater was shut out by a moving shelter which was automatically controlled with a signal from a rain detector, and three different irrigation treatments were initiated. Six plots containing the three different varieties were irrigated periodically with about $10 \mathrm{~mm}$ water every other day. A second group of six plots was kept without any water at all and the third group was kept waterlogged, during 30 days. For purposes of discussion, these three treatments were termed "irrigated", "non-irrigated" and "waterlogged", respectively. These plots were surrounded by several soybean plots. The volumetric soil moisture content at 5-10 $\mathrm{cm}$ depth in the furrow was determined by sampling every two days, although these values were not representative of the whole moisture profile but indicative of moisture conditions near the soil surface. The soil moisture contents changed from 29.1 to $19.6 \%$ in irrigated plots and from 29.3 to $14.4 \%$ in non-irrigated plots, respectively.

\section{Plant, micrometeorological and remote} measurements

Three plants in each water treatment were fitted with hand-made stem flow gauges to obtain sap flow rate, which is based on the 
heat balance principle ${ }^{20)}$. Wiring of the gauges was similar to that of Steinberg et al. ${ }^{21}$. Outputs from thermocouples of the sensors were automatically recorded with a data-logger every two minutes for each five or six day period. At the end of each period of measurement, plants were sampled to determine the leaf area, and fresh and dry weights. Several other plants were also sampled from each plot for determining the leaf area index (LAI).

Photosynthesis $(\mathrm{Pn})$, transpiration $(\mathrm{Tr})$ and stomatal conductance for eight individual leaves near the top of each canopy were obtained with a portable porometer (ADC) during a period bracketing the time of solar noon by \pm one hour.

Canopy temperature and micrometeorological factors such as dry- and wet-bulb temperatures, solar radiation and windspeed were recorded every minute. The canopy temperatures were measured by infrared thermometers (Everest) from a few meters' distance. Other meteorological factors were measured at the height of $1.5 \mathrm{~m}$ in the central part of the field. The net radiation $\mathrm{Rn}$ was estimated using an empirical relationship between the solar radiation and net radiation for soybean canopies. thermal image measurements over the field were also made using a thermal imager (JEOL).

\section{A model for remote sensing of canopy transpiration}

The core of the model is based on the energy balance of a plant canopy, which uses the net radiation absorbed by the canopy and the remotely sensed canopy temperature as key inputs to the model. On the basis of the energy balance ${ }^{15)}$, canopy transpiration can be expressed as :

$$
\operatorname{Tr}_{\mathrm{c}}=\left[\mathrm{Rn}_{\mathrm{c}}-\rho \mathrm{Cp}\left(\mathrm{t}_{\mathrm{c}}-\mathrm{t}_{\mathrm{a}}\right) \mathrm{g}_{\mathrm{ah}}\right] / \lambda
$$

where $\operatorname{Tr}_{c}$ is the canopy transpiration rate, $\mathrm{Rn}_{\mathrm{c}}$ is the net radiation absorbed by the canopy, $\rho$ is the density of air, Cp is the heat capacity of air, $t_{c}$ and $t_{a}$ are the canopy and air temperatures, $g_{a h}$ is the aerodynamic conductance for heat, and $\lambda$ is the latent heat of vaporization. Using $\operatorname{Tr}_{c}$, the canopy conductance $g_{c}$ can be estimated by :

$$
\mathrm{g}_{\mathrm{c}}=\left[\mathrm{k}_{\mathrm{v}}\left(\mathrm{e}_{\mathrm{c}}{ }^{*}-\mathrm{e}_{\mathrm{a}}\right) / \operatorname{Tr}_{\mathrm{c}}-1.08 \mathrm{~g}_{\mathrm{ah}}{ }^{-1}\right]^{-1}
$$

where $k_{\mathrm{v}}$ is the conversion constant from vapor pressure to concentration, $\mathrm{e}_{\mathrm{c}}{ }^{*}$ is the saturated vapor pressure at the canopy surface temperature, and $e_{a}$ is the actual vapor pressure of the air over the canopy. The net radiation absorbed by the canopy was estimated from Eq.3 using $\mathrm{Rn}$, leaf area index LAI, and solar elevation $\theta$ which is calculated as a function of date and time.

$$
\mathrm{Rn}_{\mathrm{c}}=\mathrm{Rn}[1-\exp (-0.5 \mathrm{LAI} \operatorname{cosec} \theta)] \text { (3) }
$$

Denmead $^{5)}$ noted that a theoretical transmission process for direct radiation through a canopy of randomly distributed/oriented leaves (Eq.3 ${ }^{19)}$ was valid for application to real canopies. The application of Eq. 3 to complete diffuse-light conditions presumably cause some error. However, in the present application, such error is not subject to lead to serious misestimation since the direct and indirect radiation energy from the sun direction has the major effect on vaporization under most natural conditions. The aerodynamic conductance of the canopy was calculated using the following equation by Thom et al. $^{23)}$;

$$
\mathrm{g}_{\mathrm{ah}}=4.72\left[\ln (\mathrm{z}-\mathrm{d}) / \mathrm{z}_{0}\right]^{2} /(1+0.54 \mathrm{u})
$$
where $z$ is the reference height, $d$ is the zero plane displacement, $z_{0}$ is the roughness length, and $\mathrm{u}$ is the windspeed. We employed Eq.4 because our soybean plots were not sparse at the time of the measurements. Other equations can be used in the case of sparse vegetation canopies ${ }^{14)}$.

\section{Results and Discussion}

First, we examined the performance of hand -made stem flow gauges. Figure 1 shows the raw measurements of transpiration rates on an every-two minutes basis obtained for individual soybean plants in a certain plot (Tachinagaha; waterlogged). Calculated transpiration values for three individual plants were well-synchronized and proved to respond quickly to the change of environmental conditions such as solar radiation and windspeed. Since the time constant of the stem flow gauge is usually less than one minute ${ }^{2)}$, data in Fig. 1 probably indicate the realistic dynamic change of sap flow in the plant stem. Under cloudy conditions, transpiration rates and plant-toplant differences were very small. Under clear sky conditions, transpiration values were high and the plant-to-plant difference tended to increase. The plant-to-plant difference was apparently dominated by the difference in the plant size (mean leaf area of three plants in each plot ranged from $2560 \mathrm{~cm}^{2}$ to $4520 \mathrm{~cm}^{2}$; 
$\mathrm{CV}$ in each plot was around $4 \%$ ). In fact, the transpiration values on a unit leaf-area basis calculated for three plants were almost equivalent in all plots. The relatively large plant-toplant difference found under clear sky conditions was presumably caused by the different radiation regimes such as the ratio of direct and indirect radiation or radiation profile around each plant since the micro-environmental uniformity within a canopy is usually less under direct sunlight of high intensity than under mild scattered light. On a windy day, values were apt to fluctuate quickly and some extreme values were also found (Fig. lc). As Cohen ${ }^{4)}$ pointed out, the gauge or even sap flow itself may not be able to respond to such rapid dynamic environmental changes as gustiness. Hence, all raw data were smoothed using a binomial filter and ten-minute average values were used for subsequent analysis.

Figure 2 shows the canopy transpiration rates in the three differentially irrigated plots. The canopy transpiration per unit land area in each plot was estimated as a product of the mean value of leaf transpiration rates of three replicate plants and LAI for each plot (ranged from 3.4 to 5.1 ). The transpiration rate per unit leaf area for each plant was calculated from the sap flow rate measured by the stem flow gauge and the leaf area of the plant obtained by sampling. Little difference in canopy transpiration between the treatments was found until about ten days after the initiation of the treatments. About two weeks later, however, there were very clear differences between the treatments both under cloudy and clear sky conditons (Fig. $2 \mathrm{~b}$ and $2 \mathrm{c}$ ). The amount of transpired water was greatly different between treatments, especially under clear sky conditions. Canopy temperature observations with an thermal imager also showed a very clear visual difference between stressed and non-stressed treatments as reported by Inoue $^{9)}$. Under the solar radiation of high intensity, Tachinagaha in the waterloged plot were transpiring at surprisingly high rates, while the water use efficiency was not necessarily high in comparison with those in the irrigated $\operatorname{plot}^{10)}$. Tachinagaha showed a noticeable recovery in both photosynthesis and transpiration rates after the anaerobic depression just after the initiation of waterlogging treat-

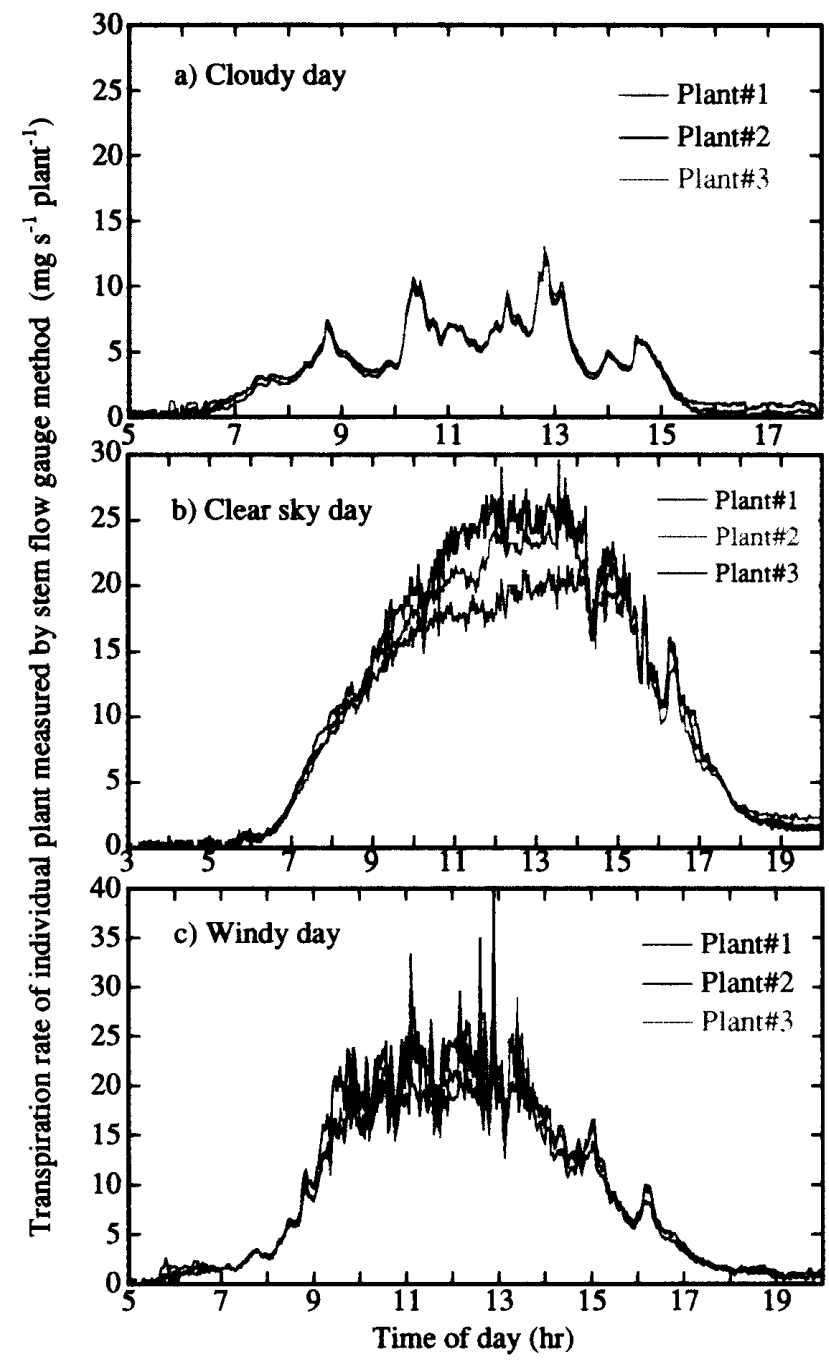

Fig. 1. Diurnal change of transpiration rate of individual soybean plant measured by stem flow gauge method under a) cloudy, b) clear sky, and c) windy conditions.

ment, while the other varieties did not show such remarkable recovery. Surprisingly, the section area at the base of a plant stem of waterlogged Tachinagaha was nearly doubled in comparison with those in the other two treatments.

We compared the canopy transpiration rates estimated by the remote method with those measured directly by the stem flow gauge method. Figure 3 shows the diurnal course of canopy transpiration values estimated by the two methods (Tachinagaha; irrigated). A good agreement are obtained between the two estimates under both cloudy and clear sky conditions for the whole day. The provisional decrease found at around 11: 00 in Fig. $3 \mathrm{~b}$ was likely caused by a cloud 


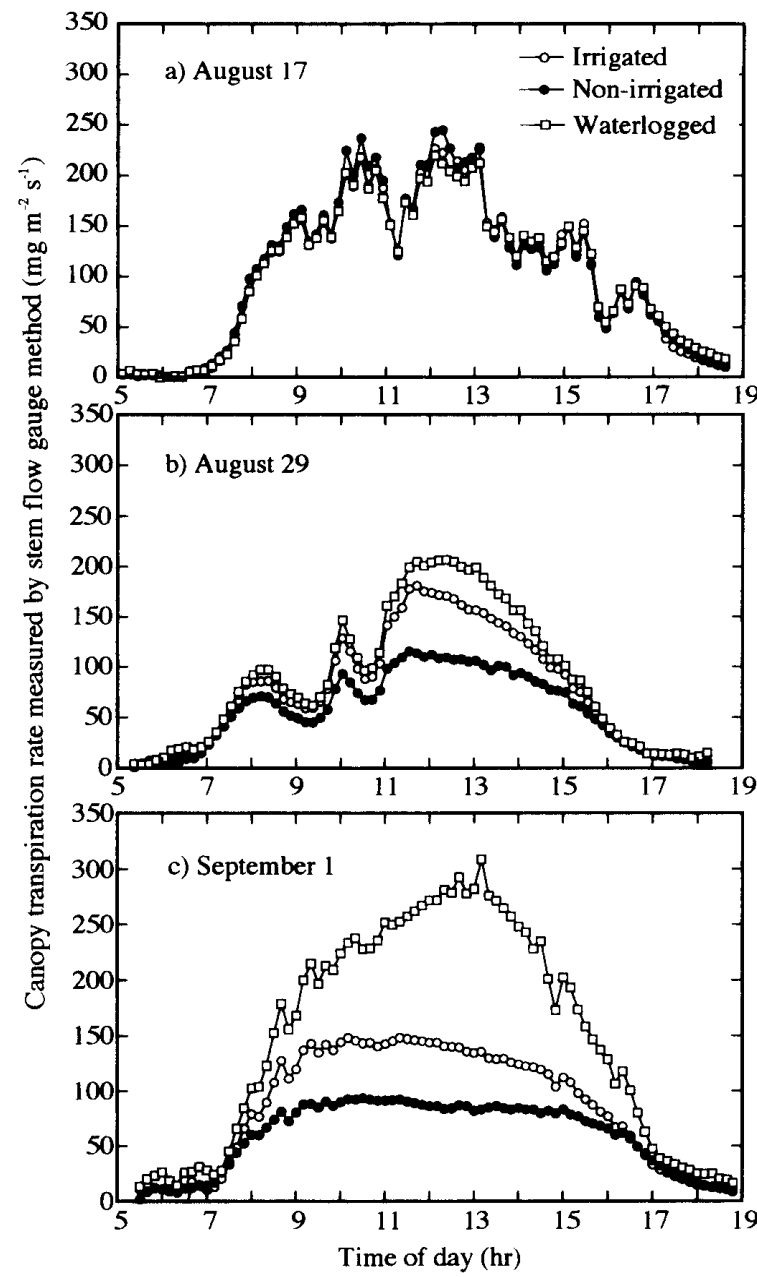

Fig. 2. Diurnal change of canopy transpiration rates measured by stem flow gauge method in three differentially-irrigated soybean plots on three typical days.

passing over the experimental field. The comparison of transpiration values in all three different treatments on a particular day (Tachinagaha; August 29) is shown in Fig. 4. There is a good correlation between the direct and remotely-estimated canopy transpiration rates irrespective of the extreme soil water conditions. Similar good correlation was also found in all other days. A systematic bias found in the irrigated plots is likely caused by a simple application of an empirical equation to the estimation of Rn. Furthermore, we compared the two methods on a daily basis based on data from the entire experimental period (Fig. 5), since daily total values of canopy transpiration would be practical for irrigation management and ecological studies on natural vegetation. Estimates for all nonstressed and severely-stressed canopies under

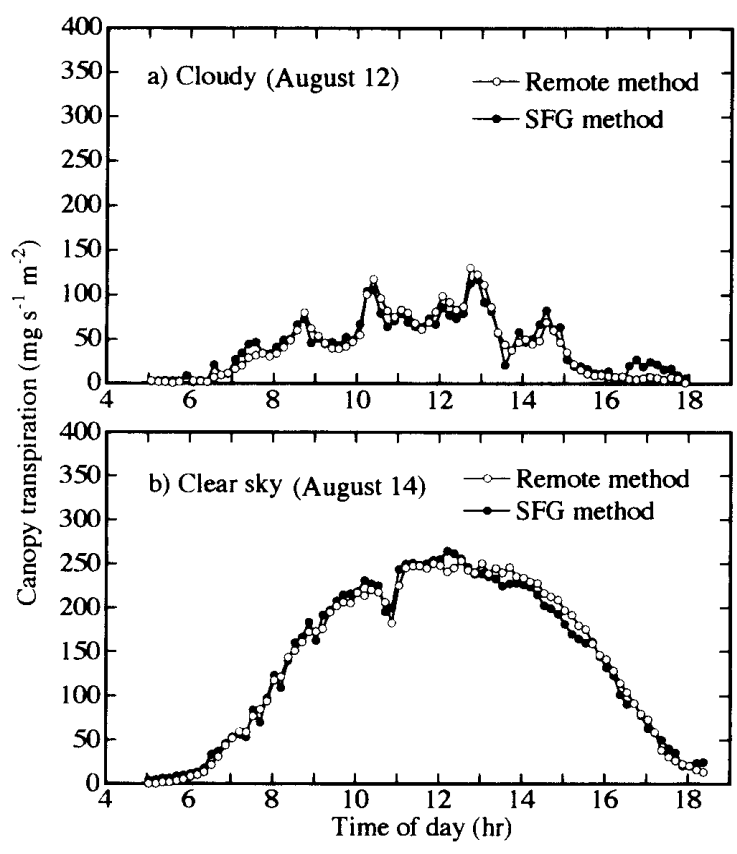

Fig. 3. Diurnal comparison of ten-minute averages of canopy transpiration rates estimated by remote and stem flow gauge methods under a) cloudy and b) clear sky conditions. All data are from a plot of irrigated $\mathrm{Ta}$ chinagaha.

various climatic conditions were well correlated with each other, the regression line being very close to the $1: 1$ line.

Canopy conductance values were also estimated by the remote and stem flow gauge methods using Eq.2. Since the stem flow gauge method needs to utilizes the canopy surface temperature measurements for calculation of canopy conductance, conductance values esstimated by the two methods were also very well correlated. Figure 6 shows the diurnal change of canopy conductance values estimated by the remote method on a particular day (August 29). The diurnal pattern seemed quite reasonable, in accordance with the three different soil water conditions, corresponding very well with the trend of canopy transpiration rates on the same day which is shown in Fig. 2b. Among the three plots, larger differences were found in the canopy conductance values than in transpiration rates. It is presumably attributed to a negative feedback loop in the relationship between conductance, transpiration and vapor pressure deficit. That is, the transpiration rate cannot be decreased proportionally with the decreasing conductance because lowered transpiration increases leaf 


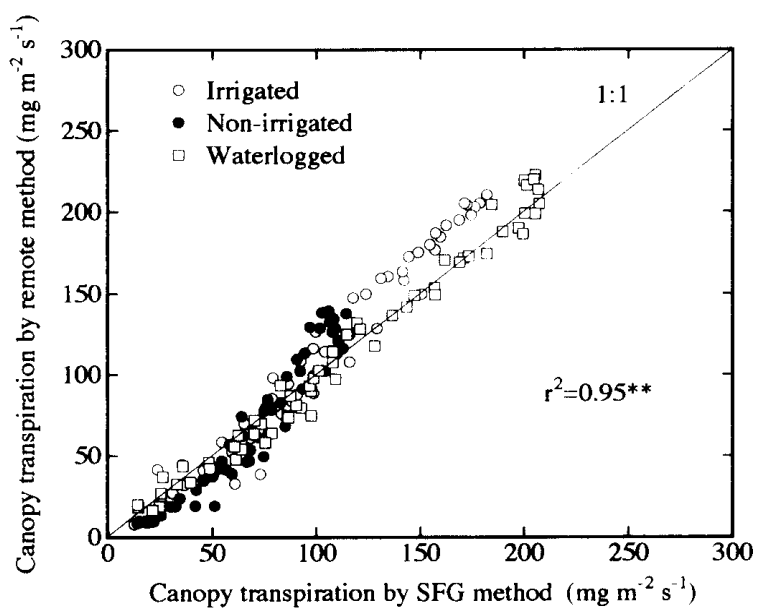

Fig. 4. Comparison of ten-minute averages of canopy transpiration rates estimated by remote and stem flow gauge methods in three differentially-irrigated soybean canopies.

temperature and subsequently the vapor pressure deficit which in turn accelerates vaporization.

In this analysis, the model utilized the LAI values obtained by plant sampling because the stem flow gauge method required the destructive measurements of the stem diameter and leaf area of each plant at the end of each measurement period. Also, an empirical relationship was used for estimating $\mathrm{Rn}$ from the solar radiation, which may have led to some systematic bias in the estimation (such as found in Fig. 4) because the equation neglected differences in the soil/water surface property. The $\mathrm{Rn}$ had better be measured directly unless some better method is available for the more accurate estimation. In the near future, anyhow, $\mathrm{Rn}$ as well as LAI will be estimated by remote means ${ }^{1,6,24)}$.

Another point to be examined is how to obtain an accurate temperature of the plant alone in the case of sparse canopies since the infrared thermal observation of plants is subject to be affected by the temperature of soil background. Nevertheless, the plant temperature alone can be extracted directly from thermal images as shown by Inoue ${ }^{9)}$. Also, there would likely be an influence of soil temperature on $\mathrm{Rn}_{\mathrm{c}}$ in sparse canopies. Thus, further examination of the method is required, especially for an application to sparse canopies.

During the experiments, leaf transpiration rate was also measured by a porometer on individual leaves near the top of a canopy

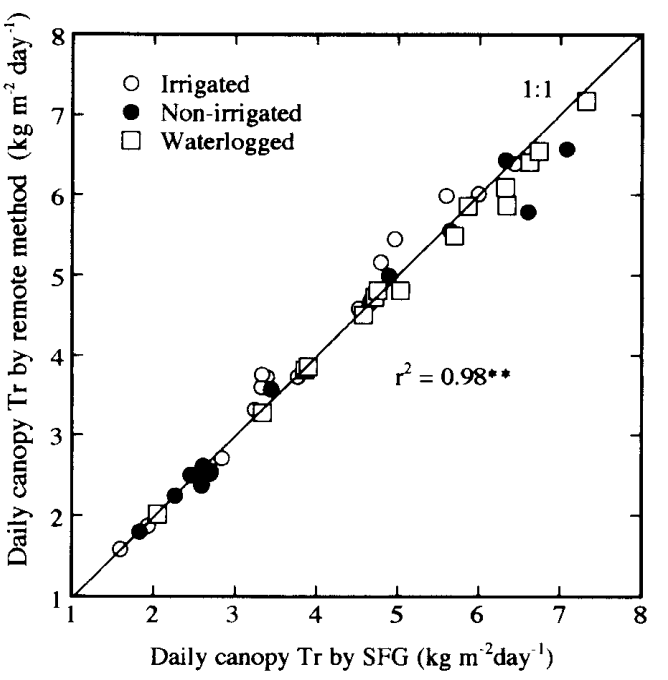

Fig. 5. Comparison of daily canopy transpiration rates estimated by remote and stem flow gauge methods.

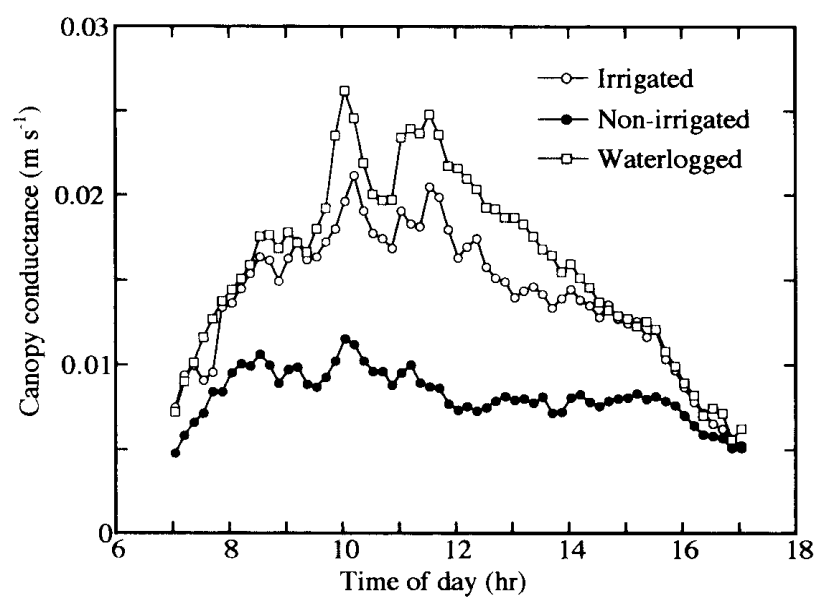

Fig. 6. Diurnal comparison of canopy conductance values estimated by remote method in three differentially-irrigated soybean canopies.

(data not shown). Those values were well correlated with the mean leaf transpiration rates per unit leaf area calculated from sap flow rates and the leaf area for a whole plant. However, the former values were three to five times as great as the latter values. This great difference seemed to be caused partly by the micro-environmental difference around leaves at each layer of the canopy, and partly by a problem peculiar to the porometry. Care should be taken in the use of leaf transpiration values measured by a porometer because there is a great difference in the leaf transpiration rate along a canopy profile. This fact was one of the major reasons that we incorporated the 
factor $\mathrm{Rn}_{\mathrm{c}}$ (absorbed net radiation by a whole plant canopy) into the model because $\mathrm{Rn}_{\mathrm{c}}$ can represent the total energy source for vaporization for the whole profile of the canopy.

The remote method based on the measurements of canopy surface temperature proved to give the reasonable estimates of canopy transpiration and conductance under a wide range of soil water and micrometeorological conditions. The method will allow continuous measurements of these canopy parameters in the open field with neither plant sampling nor disturbing the micrometeorological environment of the canopy.

\section{Acknowledgments}

We are grateful to Dr. Moran, M.S. and Clarke, T.R. for their careful review and helpful comments, and also to Dr. Kokubun, M. for kindly providing us with soybean seeds.

\section{References}

1. Asrar, G., L.E. Hipps and E.T. Kanemasu 1984. Estimating absorbed photosynthetic radiation and leaf area index from spectral reflectance in wheat. Agron. J. $76: 300-306$.

2. Baker, J.M. and C.H.M. van Bavel 1987. Measurement of mass flow of water in the stems of herbaceous plants. Plant Cell Environ. 10:777-. 782.

3. Cohen, Y., M. Fuchs, V. Falkenflug and S. Moreshet 1988. Calibrated heat pulse method for determining water uptake in cotton. Agron J. 80 : $398-402$.

4. Cohen, Y., S. Takeuchi, J. Nozaka and T. Yano 1993. Accuracy of sap flow measurement using heat balance and heat pulse methods. Agron. J. $85: 1080-1086$.

5. Denmead, O.T. 1976. Temperate cereals. In Monteith, J.L. ed., Vegetation and the Atmosphere. Vol. 2 Academic Press, New York. 1-31.

6. Heute, A.R. 1988. A soil adjusted vegetation index (SAVI). Remote Sens. Environ. 25 : 295-309.

7. Idso, S.B., R.D. Jackson, P.J. Pinter, Jr., R.J. Reginato and J.L. Hatfield 1981. Normalizing the stress-degree days for environmental variability. Agric. Meteorol. $24: 45--55$.

8. Inoue, Y., B.A. Kimball, R.J. Jackson, P.J. Pinter, Jr. and R.J. Reginato 1990. Remote estimation of leaf transpiration rate and stomatal resistance based on infrared thermometry. Agric. For. Meteorol. $51: 21-33$.

9. Inoue, Y. 1990. Remote detection of physiological depression in crop plants with infrared thermal imagery. Jpn. J. Crop Sci. $59: 762-768$.

10. Inoue, Y., S. Morinaga and M. Shibayama 1993.
Distinctive response of photosynthetic rate and water use efficiency in three soybean varieties to waterlogging and drought-stress. Jpn. J. Crop Sci. $62: 638-640$.

11. Jackson, R.D., S.B. Idso, R.J. Reginato and P.J. Pinter, Jr. 1981. Canopy temperature as a crop water stress indicator. Water Resour. Res. 17 : $1133-1138$.

12. Jackson, R.D. 1985. Evaluating evapotranspiration at local and regional scales. Proc. IEEE. 73 : $1086-1096$.

13. Jarvis, P.G. 1993. The big leaf in the real world. Proc. Int. Bot. Congr. 41.

14. Kustas, W.P., B.J. Choudhury, M.S. Moran, R.J. Reginato, R.D. Jackson, L.W. Gay and H.L. Weaver 1989. Determination of sensible heat flux over sparse canopy using thermal infrared data. Agric. For. Meteorol. 44: 197-216.

15. Monteith, J.L. and M.H. Unsworth 1990. Principles of Environmental Physics. Edward Arnold, London. 1-291.

16. Moran, M.S., R.D. Jackson, L.H. Laymond, L.W. Gay and P.N. Slater 1989. Mapping surface energy components by combining Landsat Thematic Mapper and ground-based meteorological data. Remote Sens. Environ. 30:77-87.

17. O'Toole, J.G., N.C. Turner, O.P. Namuco, M. Dingkuhn, and A. Gomez 1984. Comparison of some crop water stress measurement methods. Crop Sci. 24: 1121-1128.

18. Reginato, R.J., R.D. Jackson and P.J. Pinter, Jr. 1985. Evapotranspiration calculated from remote multispectral and ground station meteorological data. Agric. For. Meteorol. 18: 75-89.

19. Ross, J. 1975. Radiative transfer in plant communities. In Monteith, J.L. ed., Vegetation and the Atmosphere. Academic Press, New York. 13-55.

20. Sakuratani, T. 1984. Improvement of the probe for measuring water flow rate in intact plants with the stem heat balance method. J. Agric. Meteorol. $40: 273-277$.

21. Steinberg, S.L., C.H.M. van Bavel and M.J. McFarland 1990. Improved sap flow gauge for woody and herbaceous plants. Agron. J. $82: 851$ $-854$.

22. Tanner, C.B. and T.R. Sinclair 1983. Efficient water use in crop production : Research or $\mathrm{Re}^{-}$ search? In Taylor, H.M. et al. eds., Limitations to Efficient Water Use in Crop Production. American Soc. Agron. 1-27.

23. Thom, A.S. and H.R. Oliver 1977. On Penman's equation for estimating regional evaporation. Q.J. R. Meteorol. Soc. $103: 345-357$.

24. Weigand, G.L., A.J. Richardson, D.E. Escobar and A.H. Gerbermann 1991. Vegetation indices and crop assessments. Remote Sens. Environ. 35 : $105-119$.

25. WMO 1988. Water resources and climatic change : Sensitivity of water resource systems to climate change and variability. WCRP - 4, Geneva. 